\title{
Bio-Scouring of Cotton using Protease and Pectinase from Bacillus subtilis Isolated from Market Waste
}

\section{Chidiebere Anab-Atulomah ${ }^{1}$, Ejikeme Nwachukwu ${ }^{1}$}

\author{
${ }^{1}$ Michael Okpara University of Agriculture \\ PMB 7267, Umuahia Umudike, Abia State, Nigeria
}

\section{DOI: $10.22178 /$ pos. $72-3$ \\ LCC Subject Category: QH540-549.5}

Received 20.06.2021

Accepted 28.07.2021

Published online 37.07.2021

Corresponding Author:

Chidiebere Anab-Atulomah

anab.chidiebere@mouau.edu.ng

(c) 2021 The Authors. This article

is licensed under a Creative

Commons Attribution 4.0

License @

\begin{abstract}
The bio-scouring of cotton using protease and pectinase produced from Bacillus subtilis was investigated. Protease and pectinase were produced from Bacillus subtilis in a liquid medium using the submerged fermentation technique. Both enzymes were purified, and their scouring potential was tested on raw cotton fabrics. Pectinase was more effective than protease under optimised conditions. The optimum scouring temperature for both enzymes was between $40{ }^{\circ} \mathrm{C}$ and $50{ }^{\circ} \mathrm{C}$, with pectinase bio-scoured fabric showing $15.5 \%$ weight loss while protease bio-scoured fabric had $14.3 \%$ weight loss. The optimum $\mathrm{pH}$ for pectinase scouring was $\mathrm{pH} 9$ with $14.8 \%$ weight loss in the fabric, while the optimum $\mathrm{pH}$ for protease scoured fabric was $\mathrm{pH} 7$ with $12.3 \%$ weight loss in fabric. After 120 minutes of bioscouring, maximum weight loss was recorded for both pectinase and protease treated fabrics. The application of protease and pectinase for cotton fabric scouring revealed that they could be used as bio-scouring agents to treat textile materials.
\end{abstract}

Keywords: bio-scouring; cotton; Bacillus subtilis; protease; pectinase.

\section{INTRODUCTION}

Cotton is the most valuable natural source of cellulose, and its use is constantly increasing. It is highly hydrophobic and slightly coloured [5]. Pre-treatment processes are needed to prepare cotton fibres for further treatment and use, including scouring and bleaching. In these treatments, vast amounts of auxiliary agents are added. Due to the high operational temperatures, a lot of energy is consumed. Large volumes of water are used to rinse and deactivate the alkalinescoured and bleached fabrics. Conventional scouring of cotton involves alkali (soda ash and caustic ash) and detergents to remove waxes, fats, pectin, mineral salts and other impurities from raw cotton fabrics [10]. This process effectively removes impurities but has a high demand for energy, water and auxiliary agents. The effluent generated is also ecologically undesirable. These chemicals also attack cellulose leading to heavy strength loss and weight loss in the fabric. These setbacks have led to alternative processes such as bio-scouring being considered. Bio- scouring is a novel process based on the usage of particular enzymes to remove impurities from textile materials [9].

Consequently, the textile industry is considered one of the most extensive energy, water and chemical consumers. To adapt to the increasingly more rigorous environmental regulations and save energy and water, biotechnology-based alternatives such as the application of enzymes have been applied in the textile sector. For example, Bio-scouring with enzymes such as pectinase and protease is an alternative to alkali scouring to eliminate non-cellulose substances from the cotton-fibre surface.

The process can occur at moderate temperatures in a slightly acidic or alkaline medium, depending on the type and nature of the enzyme used. The use of enzymes in the scouring of textile materials such as cotton is gaining global recognition due to their non-toxic nature. Microorganisms are the best sources of industrial enzymes as their production is economically viable with low resource consumption and low emissions [1]. 
Enzymatic treatment of textiles is of great interest as it is effective under mild treatment conditions [6].

Enzymes such as pectinase and protease can be produced from bacteria and fungi using different fermentation procedures such as Solid-State Fermentation and Submerged fermentation under enhanced conditions [8]. Proteases catalyse the hydrolysis of proteins and are of different serine, alkaline, acidic, neutral and carboxyl proteases. They are produced extracellularly by microbes such as bacteria and fungi [11]. Pectinases catalyse the breakdown of pectin, a polysaccharide found in plant tissues, into smaller molecules. Both enzymes are of industrial importance. They are used in leather processing, food industries, textiles and pharmaceuticals. Bacillus subtilis is a widely used bacteria for the industrial production of enzymes such as amylase, pectinase and protease. They are Gram-positive bacteria found commonly in soil and below vegetation [4]. Markets in third world countries like Nigeria are sources of large amounts of waste of plant and animal origin. Hence, they are a ready source of microorganisms that can easily be cultured for different metabolic products such as enzymes.

\section{METHODS}

Collection of Materials and Samples. Three yards of raw cotton fibres were purchased from Kano Textile Mill, Nigeria. A 50 g mixed market solid waste sample of animal and plant origin was aseptically collected from Orie Ugba market, Umuahia, Abia State Nigeria in sterile containers and labelled.

Microorganism and Enzyme Production. Bacillus subtilis was isolated from waste samples collected from Orie Ugba Market, Umuahia, Abia State, Nigeria. It was identified based on cellular morphology, Gram's staining, biochemical tests and confirmed using the 16S rRNA method.

Bacillus subtilis was screened for protease production by streaking on skim milk agar plates and incubated at $37^{\circ} \mathrm{C}$ for 24 hours, after which the plates were analysed for zones of hydrolysis [2]. They were screened for pectinase production using Pectin Agar Medium. They were streaked on pectin agar plates and incubated at $37^{\circ} \mathrm{C}$ for 24 hours, after which the plates were flooded with $3.3 \%$ Cetyltrimethyl Ammonium Bro- mide solution. Zones of hydrolysis were analysed [7].

Production of protease enzyme was carried out using liquid medium containing $1 \mathrm{ml}$ gelatin $\mathrm{w} / \mathrm{v}$, $0.5 \mathrm{ml}$ of yeast extract and $100 \mathrm{ml}$ distilled water at $\mathrm{pH}$ seven was inoculated with $1 \%$ inoculums of 24 hours old B. subtilis culture. The flasks were incubated at $40^{\circ} \mathrm{C}$ for 24 hours on a rotary shaker maintained at $150 \mathrm{rpm}$. After 24 hours, the broth was centrifuged at $5000 \mathrm{rpm}$ at $4{ }^{\circ} \mathrm{C}$ for 20 minutes, and the cell-free supernatant was collected (crude enzyme) [2]. The crude enzyme was purified in stages using ammonium sulphate precipitation, dialysis and diethyl aminoethyl (DEAE) Column Chromatography [2]. Protease activity was determined using the caseinolytic method (Anson's modified method). One unit of the enzyme was defined as the amount of enzyme that liberates peptide fragments equivalent to $1 \mathrm{mg}$ of bovine serum albumin (BSA) under the assay condition [13].

Production of pectinase was done using an essential liquid medium having a composition of 1\% Pectin, $0.14 \%$ Ammonium dihydrogen sulphate, $0.2 \%$ Potassium dihydrogen phosphate, $0.6 \%$ Potassium hydrogen phosphate and $100 \mathrm{ml}$ distilled water at $\mathrm{pH}$ 7. It was inoculated with $1 \mathrm{ml}$ inoculum of 24 holds B. subtilis culture $(1 \times 108 \mathrm{CFU} / \mathrm{ml})$. The flasks were incubated at $40{ }^{\circ} \mathrm{C}$ for 24 hours on a rotary shaker to be maintained at $150 \mathrm{rpm}$. After 24 hours, the broth was centrifuged at $5000 \mathrm{rpm}$ at $4^{\circ} \mathrm{C}$ for $20 \mathrm{~min}$, and the cell-free supernatant was collected. The supernatant was used as crude enzyme extract [1] and subsequently purified [2]. Pectinase activity was measured by estimating D-galacturonic acid by dinitrosalicylic acid (DNS) with pectin as substrate [12].

Scouring. The raw cotton fibre was treated to conventional scouring using sodium carbonate and bio-scouring using pectinase and protease.

Conventional scouring was carried out at $\mathrm{pH} 10$ for two $\mathrm{h}$ at $40^{\circ} \mathrm{C}$. The solution for scouring contained $2 \mathrm{~g} / \mathrm{L}$ Auxipon NP solution (non-ionic surfactant) phosphate buffer $\mathrm{pH} 10$ and $3 \mathrm{~g} / \mathrm{L}$ sodium carbonate solution (alkali). Material to liquor ratio (MLR) was kept at 1:30. The sample was first designed with a hot wash. The fibres were then dried in an oven [3].

Different parameters of bio-scouring, namely buffer $\mathrm{pH}$, enzyme concentration, temperature 
and period, were optimised to examine the efficiency of protease and pectinase.

Exactly $10 \mathrm{~g}$ of the raw cotton fibre samples were suspended in the $\mathrm{pH}$ buffer ranging from 3.0 to 11.0. Material to Liquid Ratio (MLR) was set at 1:30 with a varying dosage of enzyme in the range of $25 \%$ to $75 \%$ on fabric weight for a treatment time of $30,60,90,120$ and 150 minutes at different temperatures ranging from 30 to $70{ }^{\circ} \mathrm{C}$. The bio-scouring process optimisation was carried out by varying one parameter simultaneously, keeping other factors constant. The experiments were performed in a water bath. After the enzymatic treatment, the fibres were given hot wash at boiling temperature for 30 minutes, air-dried and dried in a desiccator for 24 hours. The efficiency of bio-scouring for each parameter was evaluated by monitoring the weight loss of the fibres as the difference before and after the bio scouring treatment [3].

Enzyme-treated and untreated cotton fibres were conditioned at $20 \pm \mathrm{I}^{\circ} \mathrm{C}$ at least $24 \mathrm{~h}$ before being weighed. Weight loss was expressed as:

$$
\text { weight loss, } \%=\frac{w_{1}-w_{2}}{w_{1}} \times 100,
$$

where $w_{1}$ is the conditioned weight of the sample before enzymatic treatment, and $w_{2}$ is the conditioned weight of the sample after enzymatic treatment, respectively [14].

Statistical Analysis. One-way Analysis of Variance (ANOVA) was used to analyse the data generated using R.

\section{RESULTS}

Protease Production and Assay. Protease exhibited maximum activity of $8.7 \mathrm{U} / \mathrm{ml}$ after optimising various parameters and undergoing purification.

Pectinase Production and Assay. Purified pectinase exhibited maximum activity of $8.9 \mathrm{U} / \mathrm{ml}$ after optimising various parameters.

Bio-scouring. Raw cotton fibres were subjected to different scouring treatments. Scouring activity was determined by measuring weight loss.

The effect of different concentrations of alkali, pectinase and protease on the scouring of cotton fabrics was investigated. There was a significant difference in alkali scoured fabrics in comparison to enzyme scoured fabrics. From Figure 1, it is observed that under different concentrations, pectinase scoured fabrics exhibited a significant decrease in weight $(\mathrm{p}<0.05)$ than in protease scoured fabrics with $15.3 \%$ weight loss at $80 \%$ concentration in the scoured fabric.

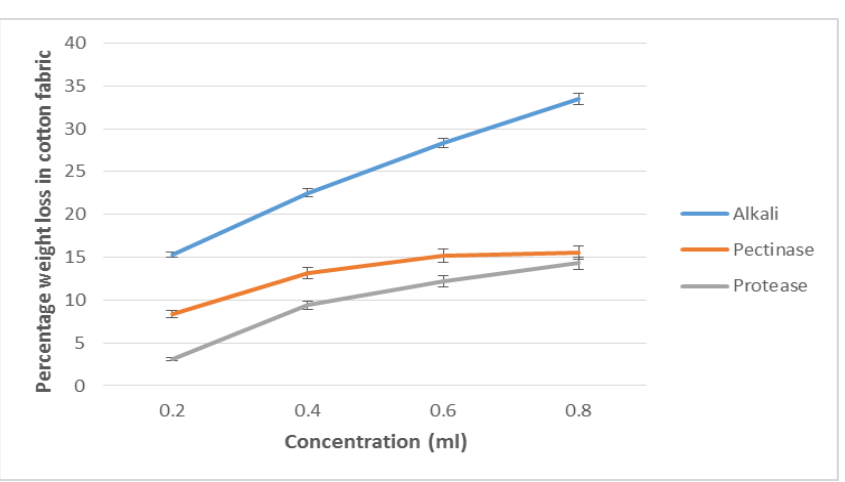

Figure 1 - Effect of different concentrations of alkali, pectinase and protease on cotton fabric

However, there was more significant weight loss in alkaline scouring at $80 \%$ concentration with $33.5 \%$ weight loss in cotton fabric. As concentration increased, alkaline scoured fabrics displayed a steady rise in weight loss. For pectinase scoured fabrics, weight loss was almost even when using $60 \%$ and $80 \%$ enzyme concentrations.

The enzymes were tested for scouring ability at different temperatures. From Figure 2, it is observed that pectinase showed better scouring ability with $15.5 \%$ weight loss at $40{ }^{\circ} \mathrm{C}$ while protease showed maximum weight loss of $14.3 \%$ at $50{ }^{\circ} \mathrm{C}$, after which its scouring ability declined.

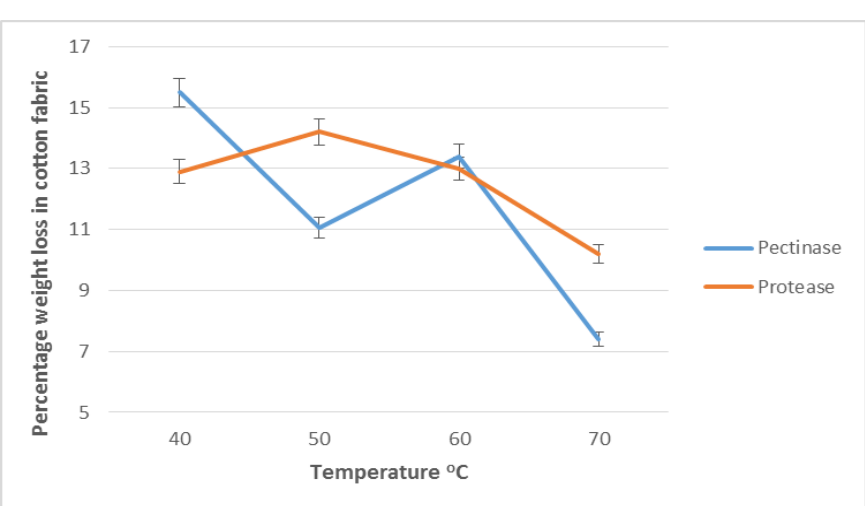

Figure 2 - Effect of different temperatures on bioscouring of cotton fabric 
Pectinase scouring ability declined after $40^{\circ} \mathrm{C}$ to $11 \%$ weight loss of cotton fabric at $50^{\circ} \mathrm{C}$. After that, the weight loss of the scoured fabric increased rapidly, declining after $60^{\circ} \mathrm{C}$. For protease scoured fabric, after peak scouring observed at $50{ }^{\circ} \mathrm{C}$, the decline was steady with a weight loss of $10.2 \%$ at $70{ }^{\circ} \mathrm{C}$.

Different time intervals for the bio-scouring of cotton fabrics were investigated. From Figure 3, it is observed that weight loss in treated cotton fabrics was higher after 120 minutes for both protease and pectinase scoured fabrics at $15.2 \%$ and $10.9 \%$, respectively, after which scouring efficacy declined. Between 60 minutes and 120 minutes of pectinase scouring, weight loss in fabric increased consistently. After an initial weight loss after 60 minutes, for protease scoured fabrics, weight loss decreased at 90 minutes but peaked at 120 minutes.

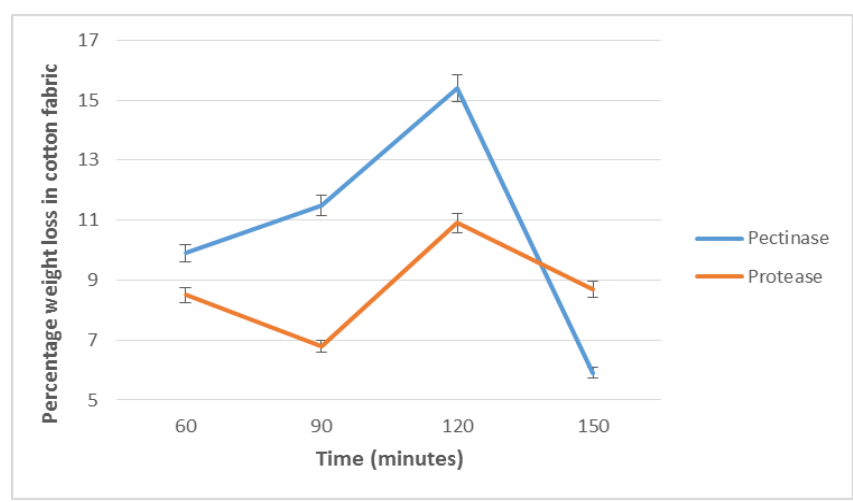

Figure 3 - Effect of different time intervals on the bioscouring of cotton fabric

Bio-scouring activity using pectinase and protease showed varying effects at different $\mathrm{pH}$. In Figure 4, it is observed that at neutral $\mathrm{pH}$, protease scoured fabrics exhibited a significant increase in weight loss $(\mathrm{p}<0.05)$ than pectinase scoured fabrics with $12.3 \%$ weight loss.

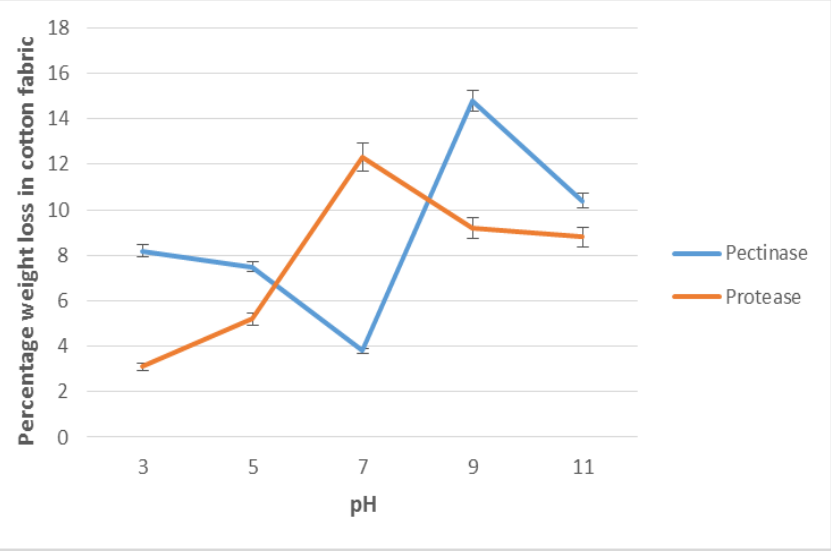

Figure 4 - Effect of different pH on bio-scouring of cotton fabric

At $\mathrm{pH}$ 9, pectinase scoured fabrics exhibited significantly fewer weight than protease scoured fabrics with $14.8 \%$ weight loss. Protease scoured fabrics displayed a steady rise in weight loss as the $\mathrm{pH}$ increased. Despite peaking at $\mathrm{pH} 7$, protease scouring was more effective under alkaline conditions than in acidic conditions. Pectinase scoured fabrics displayed low weight loss at neutral $\mathrm{pH}$ with only $3.8 \%$ weight loss. After that, there was a sharp rise in fabric weight loss peaking at $\mathrm{pH}$ 9. Pectinase scouring was more effective under alkaline conditions.

\section{DISCUSSION}

Conventional alkaline scouring of cotton fabric led to a higher weight loss than enzyme treated fabrics. The excessive loss in weight indicated damage to the secondary wall of cotton, where about $90-95 \%$ of cellulose is found. This indicates that the treatment with alkali as a scouring agent had a harsh effect on the cotton fabrics, similar to findings stated by [10]. This will also affect the strength of cotton fibres, thereby affecting fabric quality. It will also have a deleterious effect on the further processing of fabrics, such as bleaching due to reduced absorptivity of the fabric. Scouring using the purified enzymes produced from Bacillus subtilis had a milder effect on the cotton fabrics. Pectinase exhibited a higher scouring capacity than protease. This is attributed to the structure of cotton as a plant and the importance of pectin in plant cell wall composition. The pectinolytic enzyme was able to hydrolyse pectin, thereby making the removal of noncellulosic materials faster. Proteases tend to be more effective in treating materials made from animal origins, such as wool and leather. Howev- 
er, cotton fibres also contain protein materials as impurities in their primary cell wall.

Optimum scouring using both enzymes was observed at the mesophilic range, after which weight loss in fabrics was reduced. This may be attributed to the enzymes showing less activity after $60{ }^{\circ} \mathrm{C}$. The effect of higher temperatures on protease and pectinase activity on scouring reduced their activity as it denatures them, making them lose their hydrolytic property. A lower temperature was required for pectinase scouring than the protease process indicating less energy requirement when using pectinase. Optimum scouring was achieved after an extended time of enzymatic treatment using both protease and pectinase. This is similar to findings by [3] indicating that time is a critical factor in the efficient scouring of raw cotton fabrics though care must be taken to avoid damage to the fabric. Pectinase scoured fabrics displayed increased loss in weight with time until 120 minutes, after which weight loss observed was less.

\section{CONCLUSION}

The use of enzymes in white biotechnology techniques attracts wider patronage due to the obvious advantages over traditional methods. The consumption of energy and raw materials and increased awareness of environmental concerns related to the use and disposal of chemicals into landfills, water or release into the air during chemical processing of textiles are the principal reasons for the application of enzymes in finishing textile materials. Microbial extracellular enzymes are cheaper to produce and give higher yields in comparison to animal and plant sources. This can be attributed to the rapid growth of bacteria under optimised conditions. These enzymes are used in the textile industry for fabric treatment. The use of protease and pectinase in the scouring of natural fabrics reduces water consumption, thereby reducing the volume of effluent generated. Alkaline scouring produces toxic effluents, which alter the ecosystem balance when discharged into the environment. Alkaline scouring also harshly degrades fabric quality as it leads to significant weight loss compared to enzymatic scouring. This study indicates that the use of enzymes such as protease and pectinase for the bio-scouring of cotton fabrics presents a viable, cheap and eco-friendly option to conventional scouring. Therefore, Bio-scouring can be recommended as a good technique for scouring cotton fabrics. It is a simple, repeatable and safe procedure.

\section{REFERENCES}

1. Dalvi, P., Anthappan, P., Darade, N., Kanoongo, N., \& Adivarekar, R. (2007). Amylase and pectinase from single source for simultaneous desizing and scouring. Indian Journal of Fibre and Textile Research, 32, 459-465.

2. Badhe, P., Joshi, M., \& Adivarekar, R. (2016). Optimised production of extracellular proteases by Bacillus subtilis from degraded abattoir waste. Journal of Bioscience and Biotechnology, 5(1), 2936.

3. Badhe, P., Damale, M., \& Adivarekar, R. (2017). Bioscouring of wool using protease from bacillus subtilis isolated from abattoir waste. Journal of Microbiology, Biotechnology and Food Sciences, 6(4), 1012-1018. doi: 10.15414/jmbfs.2017.6.4.1012-1018

4. Bandow, J. E., Brötz, H., \& Hecker, M. (2002). Bacillus subtilis Tolerance of Moderate Concentrations of Rifampin Involves the $\sigma B$-Dependent General and Multiple Stress Response. Journal of Bacteriology, 184(2), 459-467. doi: 10.1128/jb.184.2.459-467.2002

5. Boylston, E. K., \& Usda, J. J. H. (1995). The Primary Wall of Cotton Fibers. Textile Research Journal, 65(7), 429-431. doi: 10.1177/004051759506500711

6. Deng, A., Wu, J., Zhang, Y., Zhang, G., \& Wen, T. (2010). Purification and characterization of a surfactant-stable high-alkaline protease from Bacillus sp. B001. Bioresource Technology, 101(18), 7100-7106. doi: 10.1016/j.biortech.2010.03.130

7. Kobayashi, T., Koike, K., Yoshimatsu, T., Higaki, N., Suzumatsu, A., Ozawa, T., ... Ito, S. (1999). Purification and Properties of a Low-molecular-weight, High-alkaline Pectate Lyase from an 
Alkaliphilic Strain ofBacillus. Bioscience, Biotechnology, and Biochemistry, 63(1), 65-72. doi: $10.1271 /$ bbb.63.65

8. Machado, C. M. M., Oishi, B. O., Pandey, A., \& Soccol, C. R. (2004). Kinetics of Gibberella fujikuroi Growth and Gibberellic Acid Production by Solid-State Fermentation in a Packed-Bed Column Bioreactor. Biotechnology Progress, 20(5), 1449-1453. doi: 10.1021/bp049819x

9. Teli, M., \& Adere, T. (2016). Process optimisation for bioscouring of $100 \%$ cotton textiles using BoxBehnken design. Advances in Applied Science Research, 7(4), 209- 221.

10. Mojsov, K. (2012). Microbial Alpha-Amylases and their Industrial Applications: A Review. International Journal of Management, IT and Engineering, 2(10), 583-609.

11. Mala, B. R., Aparna, M. T., Mohini, S. G., Vasanti, V. D. (1998). Molecular and Biotechnological Aspects of Microbial Proteases. Microbiology and Molecular Biology Review, 62(3), 597-635.

12. Kavuthodi, B., Thomas, S., \& Sebastian, D. (2015). Co-production of Pectinase and Biosurfactant by the Newly Isolated Strain Bacillus subtilis BKDS1. British Microbiology Research Journal, 10(2), 112. doi: $10.9734 / \mathrm{bmrj} / 2015 / 19627$

13. Muthulakshmi, Ch., Gomathi, D., Kumar, D. G., Ravikumar, G., Kalaiselvi, M., \& Uma, Ch. (2011). Production, purification and characterisation of protease by Aspergillus flavus under solid state fermentation. Jordan Journal of Biological Sciences, 4(3), 137-148.

14. Waddell, R. (2002). Bioscouring of cotton: commercial applications of alkaline stable pectinase. AATCC Review, 2, 28-30. 